thebmj

\title{
Editorials
}

\section{How cognitive biases affect our interpretation of political messages}

BMJ 2010; 340 doi: http://dx.doi.org/10.1136/bmj.c2276 (Published 27 April 2010) Cite this as: BMJ 2010;340:c2276

\author{
Martin McKee, professor of European public health1, David Stuckler, research fellow2 \\ ${ }^{1}$ London School of Hygiene and Tropical Medicine, London WC1E 7HT \\ ${ }^{2}$ Christchurch College, University of Oxford, Oxford OX1 1DP
}

martin.mckee@Ishtm.ac.uk

What we hear is often very different from what we are told

British readers of the $B M J$ will soon get to vote on the competing visions of the political parties at the general election. Although the mainstream parties each claim the middle ground, there are important differences in how they will approach the economic challenges that lie ahead, with potentially major implications for health and health care. How fast and how deep should cuts in public spending be? Are targets a good or a bad thing? What is the appropriate role of private healthcare providers?

Voters must decide which of the different answers they agree with, yet-as seen in recent disputes between leading economists about how to tackle the government deficit-it is possible for two well informed groups of people faced with the same evidence to reach completely different conclusions about what should be done. How do voters interpret such complex information and what influences them?

There is considerable evidence that people presented with balanced arguments place weight on those they already agree with, 1 exhibiting what is termed confirmation bias. 2 A recent study from the United States randomly allocated one of four versions of an authoritative news story about diabetes to people who had declared different political allegiances. 3 Each story was identical except for how they described the cause of diabetes. One said nothing about the cause (the control), whereas the three others cited genes, individual lifestyle choices, and social determinants. They were then asked whether they agreed with two statements on the reason people get diabetes, one specifying social determinants and the other genes. Democrats were most likely to agree that social determinants were a cause, regardless of which version they read. Independents reading the version where social determinants were the cause were more likely to agree with this explanation than those who read the control story, but the social determinants version had no effect on Republicans' views. Each group was then asked about collective actions to tackle diabetes, such as restrictions on junk food. Democrats reading the social determinants version were significantly more likely than controls to support action but Republicans were less so. In a second US study, subjects were initially categorised on a conservative-liberal scale and then exposed to 
factually incorrect stories on the effect of US tax cuts and weapons of mass destruction in Iraq followed by an authoritative correction. If they sympathised with the initial message the correction either failed to change their misperception or actually reinforced it. 4

Another study examined possible neurological mechanisms involved in interpreting political messages in the run-up to the 2004 US Presidential election. Fast magnetic resonance imaging of the brain was used in people exposed to contradictory pairs of messages that were attributed to politicians of both parties and to neutral commentators. 5 Whereas those registered as Republicans clearly identified the contradictions voiced by Democrat politicians, they saw minimal contradiction in the statements by Republicans, and vice versa. Participants were equally capable of spotting the contradictions by the neutral commentators. Rejection of obviously contradictory evidence arose from a combination of switching off neurones associated with distress and switching on those associated with positive emotions. Perversely, the latter provided a "positive reinforcement" for making biased decisions, which one of the authors described elsewhere as giving a new meaning to the term "political junkie." 6 Crucially, this processing of information and updating of preferences occurred extremely rapidly, bypassing circuits normally associated with reasoning, and it was thought to be outside the realm of conscious control.

This research highlights how views about the relationship between the individual and society, which underpins many health policies_even if they are often poorly articulated7-influence and are influenced strongly by political beliefs. Yet these beliefs are not immutable and are also shaped by circumstances, often acting at a subconscious level. 8 Americans living in areas where most welfare recipients are the same race as themselves are more sympathetic to welfare than those in areas where recipients are of a different race. 9 The media plays a part, especially where some outlets rejoice in labelling any collective action as a manifestation of the "nanny state." 10

One study took advantage of the natural experiment in which Fox News, an outlet widely identified with a right wing agenda, was rolled out across cable networks in American towns between 1996 and 2000.11 The inclusion of Fox News in cable packages was associated with a shift in voting preferences to the right, and was estimated to have persuaded $3-8 \%$ of voters to shift allegiance to the Republicans.

Politicians are often criticised for being all things to all people and for making promises that they then fail to keep. However, as this growing body of evidence shows, the problem may be less what the politicians are actually saying but rather how their words are heard and interpreted.

\section{Notes}

Cite this as: BMJ 2010;340:c2276

\section{Footnotes}

- Competing interests: Both authors have completed the Unified Competing Interest form at www.icmje.org/coi_disclosure.pdf (available on request from the corresponding author) and declare: (1) No financial support for the submitted work from anyone other than their employer; (2) No financial relationships with commercial entities that might have an interest in the submitted work; (3) No spouses, partners, or children with relationships with commercial entities that might have an interest in the submitted work; (4) No non-financial interests that may be relevant to the submitted work. 
- Provenance and peer review: Not commissioned; externally peer reviewed.

\section{References}

1. Taber CS, Lodge M. Motivated skepticism in the evaluation of political beliefs. Am J Polit Sci2006;50:755-69.

2. Taleb NN. The black swan: the impact of the highly improbable. Allen Lane, 2007.

3. Gollust SE, Lantz PM, Ubel PA. The polarizing effect of news media messages about the social determinants of health. Am J Publ Health2009;99:2160-7.

4. Nyhan B, Reifler J. When corrections fail: the persistence of political misperceptions. Polit Behav2010; doi:10.1007/s11109-010-9112-2.

5. Westen D, Kilts C, Blagov P, Harenski K, Hamann S. The neural basis of motivated reasoning: an fMRI study of emotional constraints on political judgement during the US Presidential election of 2004. J Cogn Neurosci2006;18:1947-58.

6. Westen D. The political brain. Public Affairs, 2007.

7. McKee M, Raine R. Choosing health? First choose your philosophy. Lancet2005;365:369-71.

8. Amodio DM, Jost JT, Master SL, Yee CM. Neurocognitive correlates of liberalism and conservatism. Nat Neurosci2007;10:1246-7.

9. Luttmer EFP. Group loyalty and the taste for redistribution. J Polit Econ2001;109:500-28.

10. Harsanyi D. Nanny state: how food fascists, teetotaling do-gooders, priggish moralists, and other boneheaded bureaucrats are turning America into a nation of children. Broadway, 2007.

11. Della Vigna S, Kaplan E. The Fox News effect: media bias and voting. NBER Working Paper No 12169. NBER, 2006. 